\title{
THE JUDICIAL DISCIPLINARY PROCEDURES OF THE NEW ZEALAND RUGBY FOOTBALL UNION
}

\author{
Maryanne Haggie*
}

This paper examines the model established by the New Zealand Rugby Football Union Inc (NZRFU) to deal with acts of violence on the rugby field.

Love it or hate it, rugby is a metaphor. It can be used to define and describe the good and the bad of New Zealand society... Maybe it's a truism to say that a country's national game is a clue to its national soul, but there can be few better clues. ${ }^{1}$

\section{INTRODUCTION}

International success may be one reason why there is passion for rugby in New Zealand. It shows that a small nation can succeed against bigger, more powerful adversaries. The nature of the rugby game also reflects dominant New Zealand ideals such as egalitarianism and teamwork combined with individual skills and strength. ${ }^{2}$ Rugby engages the bodies of an estimated 150,000 New Zealanders ${ }^{3}$ and many more are coaching, managing, refereeing, washing jerseys or expressing their opinions on talkback radio. Most New Zealanders have a robust opinion about rugby, whether it be positive or negative.

* This is an edited version of a paper submitted in fulfilment of the LLB(Hons) legal writing requirement.

1 Finlay McDonald The Game of Our Lives (Penguin Books Ltd, Auckland, 1996) 1.

2 See: W H Oliver and B R Williams (eds) The Oxford History of New Zealand (Oxford University Press, Wellington, 1981) 277-278.

3 Statistics New Zealand Facts About New Zealand (2 ed, Daphne Brasell \& Associates, Wellington, 1995) 130. 
The interface between sport and the law becomes relevant when society perceives sportsfield violence as going beyond acceptable boundaries. Identifying where these boundaries lie is problematic given the traditional reluctance of both sports administrators and the courts to invoke criminal sanctions for violence in sport. Part II examines violence in rugby, the limits to the consent defence, New Zealand case law on rugby violence and the likelihood of increased court action. It looks at the debate surrounding the appropriateness of internal disciplinary tribunals for sportsfield violence. Finally, it explores the criteria sports organisations must meet in order to avoid criminal prosecution of their players or judicial review of their internal disciplinary decisions.

During the 1980s, the NZRFU were challenged by a series of incidents which rocked both the sport and public confidence in rugby's administrators. The 1981 Springbok Tour was in some ways a catalyst. It not only demonstrated that the NZRFU was out of touch with community feeling but it triggered criticisms of other aspects of rugby, such as injuries to young players and violence on the field. Part III outlines the background to the establishment of the current NZRFU procedures to deal with violence in rugby and describes how they operate at local, national and international levels.

In Part IV, the main features of the NZRFU's judicial disciplinary procedures are reviewed. It concludes that the NZRFU has created an effective and fair set of disciplinary rules to deal with violence in rugby, which has been extended to international competitions. However, it notes that while the model is comprehensive, there are some problems in its application. It will be suggested that changes could be made to the NZRFU's internal disciplinary procedures to improve consistency and independence and ultimately demonstrate to the rugby community, the courts and the public that violence in rugby is decreasing.

\section{SPORT AND THE LAW}

\section{A Violence and Rugby}

Rugby involves a high level of contact and force. Intensely physical battles combined with speed, accurate passing and skilled footwork are part of its attraction and excitement. Identifying the point at which forceful, energetic play becomes violence is difficult given the inherently physical nature of the game.

Rugby Union is governed by the International Rugby Football Board (IRFB). Law 26 of the Laws of the Game of Rugby Football, states:

Foul Play is any action by a player which is contrary to the letter and spirit of the game and includes obstruction, unfair play, misconduct, dangerous play, unsporting behaviour, retaliation and repeated infringements. 
Therefore, 'foul play' is the official term for various types of conduct, including acts of violence.

What is to some a 'hard game' of rugby would be regarded by others as violence. One report on the New Zealand national provincial final in 1994 stated: "...'pressing on the edge' is a vital part of winning....and...you can add jersey pulling, stepping on someone as you stand up and sustained verbal taunting or 'sledging'."4 A former All Black listed a series of common rugby tactics which included "covert assaults on most body parts."5

Jayne Francis argues that rugby is so central to the New Zealand psyche that a much higher level of violence is acceptable than in other sports. ${ }^{6}$ Jock Phillips describes schoolboy rugby as akin to training for war $^{7}$ and rugby is criticised for "unofficial condoning" of warlike violence. ${ }^{8}$ The 1998 match between South Africa and the All Blacks was described as "a vehicle for the frail nationalism we both share...[and the]...50th skirmish in this 100-year war will be just as intense as those that have preceded it." 9 Others argue that rugby violence, being essentially a male problem, is a symbolic demonstration of society's negative attitudes towards women and homosexuals. ${ }^{10}$

The reality that violence is increasing in many sports has attracted concern. ${ }^{11}$ Edward Grayson, a leading writer on sports law, argues it is unfortunate but indisputable that violence affects all aspects of all sports throughout the world. ${ }^{12}$

\section{B Criminal Boundaries}

Section 2(1) of the Crimes Act 1961 defines assault as:

4 "Behind the Ugly Face of Rugby" The Dominion, Wellington, New Zealand, 29 October 1994, 19.

5 Chris Laidlaw in "Behind the Ugly Face of Rugby" above n 4, 19.

6 Jayne Francis "What is Barbaric Behaviour" [1997] NZLJ 121.

7 Jock Phillips "Rugby, War and the Mythology of the New Zealand Male" (1984) New Zealand Journal of History 18.

8 Lynne Star "Televised Rugby and Male Violence" (1994) 1 New Zealand Journal of Media Studies 33,34 .

9 "Dust Blown Off Flak Jackets Again" The Evening Post, Wellington, New Zealand, 24 July 1998, 19.

10 See: Lynne Star "Macho and His Brothers: Passion and Resistance in Sports Discourse" (1993) 26 Sites 54; Shona Thompson "Feminism and Rugby" (1993) 24 Journal of Physical Education New Zealand 1.

11 See: Steven J Jackson "Beauty and the Beast: A Critical Look at Sports Violence" (1993) 26/4 Journal of Physical Education New Zealand 9.

12 Edward Grayson (ed) Sport and the Law (2 ed, Butterworths, London, 1994) 24. 
the act of intentionally applying or attempting to apply force to the person of another, directly or indirectly, or threatening by an act or gesture to apply such force to the person of another

However, society accepts that those involved in sporting endeavours are not usually liable for assault. Firstly, the state's interest in prosecution, which is to protect its citizens from illegal behaviour, is overridden by the perceived benefits to society from the sport. Secondly, the participants are deemed to be impliedly consenting to conduct, which if inflicted on them outside the sportsfield, would likely incur criminal prosecution. But there are limits to both these factors.

Society benefits from sport in many ways. It provides opportunities for people to improve their health and well-being. It entertains and promotes community spirit and national pride through participation in a collective endeavour. It can build leadership and teamwork skills or be a positive outlet for life's frustrations. It creates financial benefits for sports associations, sponsors, advertisers and players. However, when conduct goes beyond acceptable levels, these benefits to society are infringed. Criminal prosecution of unlawful behaviour on the sportsfield is triggered by society viewing the "harmful effects of certain conduct as outweighing the associated benefits."13

Limits also operate in the defence of consent. However, case law shows it is difficult to identify where these limits actually operate and the threshold for determining consent is higher in sport than non-sport cases. ${ }^{14}$ The United States of America, England and Canada are more likely than Australia and New Zealand to pursue prosecutions for sportsfield violence. $^{15}$

In Canada, objective criteria are used to determine whether the consent defence applies. ${ }^{16}$ These include:

(a) the conditions in which the game was played;

(b) the nature and circumstances of the act;

(c) how much force was used;

13 Paul Farrugia "The Consent Defence: Sports Violence, Sadomasochism, and the Criminal Law" (1997) 8 AULR 472, 473 [The Consent Defence].

14 See: "Consent in Criminal Law" (1976) 75 Mich L Rev 148, 173.

15 See: Farrugia "The Consent Defence" above n 13, 484-485; Francis "What is Barbaric Behaviour?" above n 6, 121; David Gendall "New Developments: Increasing Scope for Lawyers in the Sports Arena" [1997] 480 Lawtalk 15.

16 Rv Cey (1988) 48 CCC (3d) 480. 
(d) the victim's injury, and

(e) the state of mind of the accused.

The USA distinguishes breaches of safety rules from non-safety rules, the latter being subject to penalties on the field and the former to criminal prosecution. ${ }^{17}$ In England, intentional or reckless infliction of injury must be shown. Recklessness is defined as taking an unreasonable risk. ${ }^{18}$ Recent trends in England appear to be towards more frequent prosecution. ${ }^{19}$

\section{New Zealand Case Law on Rugby Union Violence}

In New Zealand, there are few cases on sports violence and little development in the appropriate tests which would be applied. The main rugby union cases are:

1975 Police $v$ Gray $^{20}$ - Gray punched an opposing player after the final whistle. Conviction for assault.

1976 Police $v$ Tuli ${ }^{21}$ - Tuli kicked a player in the eye. Conviction for assault.

1980 Police $v \mathrm{O}^{22}$ - Kick and punch in face of opposing player. Conviction for assault.

$1991 R v$ Tevaga $a^{23}$ - Tevaga ran 25 metres down the field and punched an opposing player's jaw, breaking it. Tevaga was sinbinned for ten minutes and the Manawatu Rugby Union imposed an eight-match suspension. He was also charged with assault. Tevaga elected trial by jury and was found guilty, the jury rejecting Tevaga's defence of the implied consent of the victim. Tevaga appealed the sentence of four months periodic detention to the Court of Appeal. There, Cooke P said: ${ }^{24}$

17 Section 50, note b, Restatement of Torts (Second) 1965.

18 See: $R v$ Johnson (1986) 8 Cr App R 343; R v Billinghurst [1978] Crim LR 553; R v Davies [1991] Crim LR 70; $R$ v Bradshaw (1878) 14 Cox CCC 83.

19 Edward Grayson "Sport and the Law Update" [1997] New Law Journal 101, 102

20 Police v Gray, (3 November 1975) unreported, Magistrates Court, Otahuhu Registry, CR 133$773 / 75$.

21 Police v Tuli (16 August 1976) unreported, Magistrates Court, Wellington Registry, CR 5490/76.

22 Police v O (1980) DCR 151.

$23 R v$ Tevaga [1991] 1 NZLR 296 (CA).

$24 R v$ Tevaga above n 23, 297. 
No New Zealand precedent has been drawn to our attention and the very fact that there may not have been cases in this country in which the criminality of some assaults in the course of sporting contests has been emphasised is of some assistance to the accused.

His Honour referred to two English soccer cases ${ }^{25}$ where sentences of between two and six months imprisonment were imposed for similar offences. However, he reduced Tevaga's sentence to 100 hours community service because of Tevaga's young age and because it was his first offence, adding: ${ }^{26}$

It is necessary to emphasise ... assaults in the course of sporting contests... cannot be tolerated

by the community or the Courts. Whatever tacit acquiescence may be said to have prevailed in the past in relation to the kind of almost barbaric behaviour exemplified by this case is no longer acceptable by current standards.

Unlike other jurisdictions, the focus in New Zealand courts has not been the test for the level of consent and "while the Court in Tevaga acknowledged the less than rigorous approach that has prevailed in the past, it merely analysed the incident in terms of the vague notion of 'fair play'."27

\section{Increasing Court Action}

While there are widely-held beliefs that sport and the law do not mix and traditionally courts are reluctant to get involved, there is consensus that there will be increased court action. This is partly because civil litigation has ballooned with the emergence of professionalism in sport. ${ }^{28}$

A second reason is increasing public concern about violence. The long-held maxim of 'what happens on the field stays on the field' is being challenged. ${ }^{29}$ It is argued that "despite....the view that sports violence is better dealt with by disciplinary action on the part of relevant governing bodies, there has been a notable increase in proceedings in the

25 R v Birking (1988) 10 Cr App R (S) 303 and R v Shervill (1989) 11 Cr App R (S) 284.

$26 R v$ Tevaga above $\mathrm{n} 23,297$.

27 Farrugia "The Consent Defence" above n 13, 485.

28 Civil cases include contract disputes involving both players and coaches, transfer disputes, restraint of trade issues, compensation suits for injury and numerous intellectual property cases, particularly in the area of character merchandising. See: Mark Fewell (ed) Sports Law A Practical Guide (LBC Information Services, Sydney, 1995), P W David "Sport and the Law - A New Field for Lawyers?" [1992] NZ Recent Law Review 80.

29 "Rugby Thugs Wary of Court Penalties" Lauren Quaintance, NZ Herald, Auckland, New Zealand, 27 April 1996, 1:7. 
last twenty-five years."130 It has also been noted that "the foundations for future criminal prosecutions in this area would seem to exist. All that may be required is a willing complainant."131

\section{E Internal Disciplinary Tribunals}

\section{Who should be the arbiters?}

The debate about whether the criminal justice system should get involved in sports violence often focuses on the efficacy of internal disciplinary tribunals. Many writers say that the state should only intervene in sports violence when internal processes have failed: ${ }^{32}$

Without an adequate punishment system to control foul play, the players will...be given the licence to thuggery that the courts have been trying to withhold.

Much of the debate focuses on whether private organisations are able to properly protect the interests of society "without judicial or other governmental involvement."133

Another view is that sports administrators are best placed to deal with violence. ${ }^{34}$ Firstly, sports organisations believe they are better able to assess conduct of players because they know the game's rules and ideals and it is their responsibility to ensure player safety and enforcement of rules. Secondly, internal controls may be the only effective way to police the entire sport. Thirdly, sport has a unique status in society which entitles sports to self-regulation. Finally, criminal sanctions would overburden busy court systems and would be costly and time-consuming. ${ }^{35}$

\section{Criteria for Internal Disciplinary Tribunals}

The establishment of internal disciplinary procedures is the primary mechanism by which sports organisations deal with sportsfield violence. There are two aspects to the internal process which will be addressed. Firstly, they must be effective to reduce the likelihood of criminal prosecution and maintain public confidence in the sport's

30 Farrugia "The Consent Defence" above n 13, 477.

31 David Gendall "New Developments: Increasing Scope for Lawyers in the Sports Arena" [1997] 480 Lawtalk 15.

32 Mark James and Simon Gardiner "Touchlines and Guidelines: The Lord Advocate's Response to Sportsfield Violence" [1997] Crim L R 41, 44-45.

33 "Consent in Criminal Law" above n 14, 175.

34 See: Charles Woodhouse, "Sport and Law: Role of the Lawyer in Sport Today" [1993] NZLJ 411, 412

35 Farrugia "The Consent Defence" above n 13, 486-489. 
administrators. Secondly, their decisions and processes must be fair so that all parties believe justice has been done and the organisation can avoid judicial review.

\section{(a) Effectiveness}

Sports organisations must demonstrate to many interested parties that their internal disciplinary procedures are effective. Stakeholders include the players, public, media, sponsors, government and the courts. However, the primary purpose of their procedures, which is to reduce violence, should be uppermost in the minds of the sports organisations. A further goal is to keep criminal prosecutions of their players to a minimum.

It is said that law in its widest sense is applicable to sport at four different levels: (1) the basic playing laws, (2) the game's penal laws, (3) administrative laws, such as disciplinary tribunals and committees and (4) the national laws, both civil and criminal. ${ }^{36}$ A breach of any law in this framework can activate penalties and sports organisations usually select which level will adjudicate. Where the breach is serious, it is said that "to allow a private group to make such decisions is tantamount to a grant of a part of the state's jurisdiction." 37 Therefore, sports organisations must know the limits beyond which selection and application of internal measures is neither good for their sport nor for the wider community.

Sports organisations must be vigilant and regularly revise playing, safety and penal rules aimed at prevention of violent incidents. Inconsistency or inattention at any level may invoke public dismay and ultimately court action. If sports organisations believe that the criminal law should stay out of sport, complacency in internal measures will only indicate that what drives this concern is that sports people believe they are above the law.

Referees, administrators and players from junior to professional levels should be confident that laws will be applied equally and fairly. Sports organisations must support and communicate with match officials who invariably are the first arbiters of any foul play. Further, they need to publicly denounce sports violence and positively promote fair play principles.

\section{(b) Fairness}

The three recognised features of natural justice (or fairness) are: "(1) the right to be heard by an unbiased tribunal, (2) the right to have notice of charges of misconduct [and] (3) the right to be heard in answer to those charges."138

36 Grayson Sport and the Law above n 12, 23.

37 Farrugia "The Consent Defence" above n 13, 488.

38 Ridge v Baldwin [1964] AC 40, 132. 
While it is difficult to "commit natural justice to a system of specific rules,"139 it is essentially procedural and applies to every part of the legal process. Where the rules of domestic administrative and disciplinary tribunals are silent on the requirement for natural justice, it will be inserted by the courts and "[n]atural justice governs not only the question of guilt or innocence but also the assessment of penalty."40

How do natural justice principles impact on internal disciplinary tribunals? The following is not an exhaustive or mandatory list but summarises the main points of various writers on the subject: ${ }^{41}$

(1) Players have a right to legal representation.

(2) Players have a fair opportunity to be heard and hear the case against them.

(3) Cases are not pre-judged and the likelihood of bias is avoided.

(4) Tribunals act within their own rules and procedures.

(5) Hearsay evidence is not acted upon.

(6) Relevant matters are considered and the irrelevant disregarded.

(7) Proper services, such as interpreters, are available.

(8) There are clear boundaries between the functions of complainant, prosecutor and adjudicator.

(9) Standards of proof are generally expected to be lower than those of a court.

(10) Appropriate adjournments are granted where the offender is unavoidably detained.

(11) Each party has proper jurisdiction to cite, complain or adjudicate.

(12) Adjudicators are independent from the sport's administration.

(13) All parties are informed of the judicial process.

(14) There are adequate rights to appeal decisions.

(15) Witnesses and offenders have the right to silence.

39 J R S Forbes Disciplinary Tribunals (The Law Book Company Ltd, Sydney, 1990) 56-57.

40 Forbes Disciplinary Tribunals above n 39, 60.

41 See: Grayson Sport and the Law above n 12, 306; Forbes Disciplinary Tribunals above n 39, 57-101; "Sports Violence" [1986] Duke Law Journal 1030; G M Kelly Sport and the Law -An Australian Perspective (Law Book Company, Sydney, 1987) 67-88. 
(16) Hearings are recorded and transcripts available.

(17) Penalties are not disproportionate to the offence.

\section{F Judicial Review of Internal Disciplinary Tribunals}

One measure of the fairness of a sport's internal disciplinary procedures may be the frequency with which their decisions are challenged in court and the outcomes of those cases. But there is considerable debate about whether decisions of sports organisations should be subject to judicial review.

It is argued that judicial review is necessary because sports organisations have "monopolistic powers" over players which may be subject to abuse. ${ }^{42}$ In England, the traditional test for applicability of judicial review was the source of the organisation's authority and where the body did not derive from statute or prerogative, it was immune. However, in 1987, the English Court of Appeal held that some private bodies exercised public law functions and may be subject to judicial review. ${ }^{43}$ Since then, no categorical position has been stated. ${ }^{44}$ It is argued that England would never follow the line of reasoning in Finnegan $v$ New Zealand Rugby Football Union ${ }^{45}$ where the court allowed judicial review because of the major national importance of the issue. ${ }^{46}$

Professor Sir William Wade argues that judicial review was designed to scrutinise government decision and would be too onerous a burden on essentially voluntary organisations. He is sceptical of its application to commerce, industry or sports. ${ }^{47}$ In response, Sir Patrick Neill welcomes the "expansionist policy" because some entities have become "de facto public authorities" and he says courts should look to substance, not form, when analysing their activities. ${ }^{48}$

42 Catherine Bond "Judicial Review of the Decision[s] of Sporting Bodies" in Grayson Sport and the Law above n 12, 475-482 [Judicial Review of Sporting Bodies].

$43 R v$ Panel on Take-Overs and Mergers ex parte Datafin plc [1987] 1 QB 815.

44 See: $R v$ Jockey Club ex parte Massingberd-Mundy [1993] 2 All ER 207; $R v$ Football Association of Wales ex parte Flint Town United Football Club [1991] COD 44.

45 Finnegan $v$ New Rugby Football Union Inc [1985] NZLR 159 [Finnegan v NZRFU].

46 Bond "Judicial Review of Sporting Bodies" above n 42, 480.

47 William Wade "New Horizons in Administrative Law" in Conference Papers - The 9th Commonwealth Law Conference (Commerce Clearing House NZ Ltd, Auckland, 1990) 437, 442 [The 9th Commonwealth Law Conference].

48 Patrick Neill "A Reply to Professor Sir William Wade's 'New Horizons in Administrative Law' " in The 9th Commonwealth Law Conference above n 47, 443, 446. 
A number of factors such as increasing professionalism, pressure from sponsors and that private remedies are often unsatisfactory, may increase the likelihood of judicial review. The considerable amount of money at stake for professional players has changed the legal relationship between players and disciplinary tribunals and there is increased expectation that decisions by administrators will be strictly according to principles of natural justice. ${ }^{49}$

In New Zealand, the source of a sports organisation's authority has not been an important factor in the court's decision to grant judicial review. The NZRFU's decisions are judicially reviewable under the Judicature Amendment Act 1972. An amendment in 1977 extended judicial review to incorporated bodies, ${ }^{50}$ whose origins and constitutions were not derived from statute. The NZRFU's disciplinary decisions have been reviewed on two occasions and are discussed in Parts III and IV. ${ }^{51}$

\section{THE NZRFU'S INTERNAL DISCIPLINARY PROCEDURES}

\section{A Background}

Prior to 1991, processes for dealing with foul play in New Zealand rugby were ad-hoc and informal. Incidents were often dealt with by the coach talking to a player in the showers after the game. ${ }^{52}$ Players were seldom suspended despite some horrific behaviour. ${ }^{53}$

During the 1980s, and particularly following the 1981 Springbok Tour and the Cavaliers tour to South Africa in 1986, rugby participation, particularly among younger players, was decreasing. The perception was that rugby's administrators were out of touch with the community. Firstly, they were obdurate when faced with widespread public disapproval about the 1981 Tour. The Finnegan case in 1985 could be seen as the Court's reflection of this public disquiet when Cooke P, as he then was, said: "Whatever

49 See: Richard Evans "The Greg Williams Case - The End of 'Copping it Sweet' " [1997] Law Institute Journal 45, 46, Carlton Football Club v Australian Football League (29 May 1997) unreported, Supreme Court, Victoria, 4906/97 BC 9702142.

50 Incorporated under the Incorporated Societies Act 1908.

51 Loe v New Zealand Rugby Football Union (10 August 1993) unreported, High Court, Wellington Registry CP 209/93; Le Roux v New Zealand Rugby Football Union Inc (14 March 1995) unreported, High Court, Wellington Registry, CP 346/94.

52 R B Squire, Interview Notes, 10 July 1998. R B Squire QC often acts as Chairman of the NZRFU Judicial Committee and has largely been responsible for the revisions to the "Rules for Disciplinary Hearings" in the period 1992 - 1998.

53 D Bond, Interview Notes, 10 July 1998. Don Bond is Chairman of the Wellington Rugby Football Union and a former senior Wellington rugby player. 
may be the view of the majority opinion of those associated with the sport, there is no reason to suppose that the views of the plaintiffs are held by only a tiny or negligible minority." 54 Secondly, the lack of action by rugby's administrators on increasing violence and injuries in rugby led many parents to direct their children towards other sports. ${ }^{55}$

While the traditional stalwarts of the game remained loyal, rugby administrators recognised that more was needed to attract the broad base it usually captured. The New Zealand victory in the first Rugby World Cup in 1987 revived public interest and a fresh breed of educated younger players, known as the 'Baby Blacks' and personified by David Kirk, entered the game. ${ }^{56}$ Television coverage and sponsorship was increasing and it is argued that "through its association with television, rugby has been striving to engineer and maintain the appearance that the code has returned to a thriving endeavour closer to the cultural centrality it enjoyed prior to $1981 .{ }^{.157}$

In May 1990, the NZRFU held a meeting of hairmen of provincial disciplinary committees and decided that a more formal judicial process was required. Nevertheless, some particularly violent incidents in 1991 and 1992 attracted heavy media criticism that the NZRFU's judicial procedures were ineffectual and protectionist. In 1991, the NZRFU was accused of "dithering" after an injury caused by Alan Whetton on Stephen Bachop was graphically shown on television. ${ }^{58}$ In 1992, a two-week ban imposed on Andy Earl for a forearm jolt to an Irish player was criticised as a "pittance" and it was said that "it's ludicrous to have an All Black team manager acting as judge and jury in such cases. That may be the procedure but, in this instance, stuff the procedure. 159

During the same period, the "hard man"60 of All Black rugby, Richard Loe, was not punished for the "blatant thuggery"61 of stamping on Sam Scott-Young's head during an All Blacks test against the Wallabies. In another match, television coverage showed Loe

54 Finnegan $v$ NZRFU above $\mathrm{n} 45,179$.

55 See: Macdonald The Game of Our Lives above n 1, 107.

56 See: "Superskipper" NZ Listener Auckland, New Zealand, 25 July 1987, 20-22.

57 Lynne Star "Televised Rugby and Male Violence" above n 8, 39.

58 "League Solution Offers Rugby Prompt Means to Tackle Foul Play" Evening Post Wellington, New Zealand, 5 May 1991, 23.

59 "Stamping Out the Dirt" Spring (1992) Sports Alive, 26.

60 Ken Nicholson "Talking Tough, Talking Frank" (1998) 11 NZ Rugby Monthly 74.

61 "What a Loe Act" Spring (1992) Sports Alive, 71. 
elbowing Paul Carozza's face. The NZFRU, which said the matter was for the tour's management, were criticised for not sending Loe home. T P McLean said of the incident: ${ }^{62}$

The man plainly has brought the game into disrepute. With the best of intentions and the worst of judgements, the New Zealand council has done the same thing...Kiwis will not forget their rugby council.

\section{B The Loe Case}

On Sunday 4 October 1992 during a National Provincial Championship match between Waikato and Otago, Richard Loe eye-gouged Greg Cooper in a ruck. The referee and touch judges did not see the incident and neither the provincial union nor the NZRFU laid a complaint. The incident was caught on video and shown on a television news broadcast which led to complaints being made to the NZRFU. The Judicial Committee of the NZRFU imposed a nine months suspension on Loe, although the start of the penalty period was deferred ${ }^{63}$ because Loe had accepted a rugby position in France. After the decision, however, the French Rugby Federation terminated its arrangements with Loe. Loe appealed the suspension saying it was manifestly excessive, the hearing did not comply with the rules of natural justice, and relevant circumstances were not given proper consideration.

The Appeal Council canvassed the effect of the incident and negative publicity on Loe and his family, the financial loss because of the termination of the French position, and "outstanding references" about Loe's character and loyalty to rugby. They upheld the Judicial Committee's finding but reduced the penalty to six months. The deferred start of the sentence remained. ${ }^{64}$ Loe applied to the High Court for judicial review. ${ }^{65}$

Loe argued that the decision was unfair because he had insufficient notice of the hearing which meant his lawyers could not adequately prepare his case, call witnesses or gather other accounts of the incident. He said the NZRFU did not follow its own procedures in the consideration of the complaint or in the conduct of the hearing. He said that hyped media coverage led to complaints and, given the complainant did not attend the hearing, he could not be cross-examined by Loe's lawyer. He said material used at the hearing was not made available to Loe's counsel beforehand. The penalty, Loe submitted, was not consistent with similar incidents, nor should the start of it have been deferred.

62 "Rugged, Rough or Disreputable?" NZ Herald, Auckland, New Zealand, 25 July 1992, 2:2.

63 Richard Loe NZRFU Judicial Committee (8 October 1992).

64 Richard Loe NZRFU Appeal Council (1 April 1993) 29.

65 Loe v New Zealand Rugby Football Union Inc (10 August 1993) unreported, High Court, Wellington Registry, CP 209/93 [Loe v NZRFU]. 
Gallen J dismissed Loe's application for review stating: 66

In the end, while I think there are a number of matters to which [counsel] properly referred and which give rise to some cause for concern, I am left with the strong impression that...the NZRFU through its appropriate bodies endeavoured to act fairly and did act fairly. It seems to me that looked at overall, there is insufficient to justify the intervention of the Court in what are domestic tribunals which are appropriately set up within the game... .

His Honour emphasised that the court could only intervene if the decision-making process was flawed and would not tamper with the decision itself. He said that the NZRFU had "persons who are aware of how matches are operated and of the kind of behaviour which is considered appropriate and acceptable...during the course of such matches." 67 However, he was concerned that Loe did not have enough time to prepare his case before the hearing and should have received the video of the incident. He added that the some of the procedural rules were somewhat complex and confusing but did not consider this to be a serious issue.

His Honour thought that the penalty was relatively low given the vulnerability of the eye to injury. He had some "concern and anxiety" about the deferment of the penalty because this was not normal sentencing practice. ${ }^{68}$ However, he said Loe was hardly in a position to complain since the initial deferment was because of the French arrangements. He also accepted that the Appeal Council's decision to maintain the deferment, even after the French position was lost, was so the penalty would have effect when rugby was actually played.

Despite the NZRFU's success in court, the case highlighted some problems in the procedures, which were described as "untidy" during this period. ${ }^{69}$ Also, the NZRFU was aware that foul play incidents were not being adequately dealt with by some provincial unions. In 1993, the Chairman, Eddie Tonks, issued a union circular stating: ${ }^{70}$

[O]ver the last two years there have been a number of instances of foul play which provincial unions have not acted upon. This has harmed our game. The effect of this is that rugby administration is perceived to be weak and unwilling to deal with the problem.

66 Loe $v$ NZRFU above $\mathrm{n} 65,17$.

67 Loe $v$ NZRFU above n 65, 5 .

68 Loe $v$ NZRFU above n 65, 17.

69 R B Squire, Interview Notes, 10 July 1998.

70 NZRFU "Circular to Unions" (23 June 1993) 93/137. 
He added that foul play attracted negative media attention and promoted a poor public image. He stressed that good television ratings made potential sponsors more likely to invest and urged all unions to be proactive in dealing with foul play, the benefits being directly related to commercial income.

The NZRFU recognised that there needed to be a more formal process operated consistently by people independent of the rugby union, but who had the requisite legal skills or playing experience to be fair to players and foster the good name of rugby. ${ }^{71}$ As a result, extensive changes were made to the rules as contained in the first revised edition of the Rules for Disciplinary Hearings. It was revised again in 1996 and most recently in 1998.

\section{Rules for Disciplinary Hearings (The Black Book) ${ }^{72}$}

\section{Jurisdiction}

The Black Book applies to all local and representative rugby union games played in New Zealand by members affiliated to the NZRFU. Local games are under the jurisdiction of Union or Sub-Union Disciplinary Committees (rule2). Where the match is between separate unions (such as the National Provincial Championship), or involves representative teams, the New Zealand Maori or University Teams, the Judicial Committee of the NZRFU has the jurisdiction to hear and determine disciplinary proceedings (rule 1). The same disciplinary matters arise at both levels.

Matches played in 'Super 12' or Tri-nations competitions are subject to SANZAR ${ }^{73}$ Judicial Rules. For other international games, judicial procedures are established by the Tours Agreement between the two international unions.

All disciplinary committees are fully autonomous and their decisions are binding on the parent bodies (rules 144-146).

\section{Union and Judicial Committee Hearings}

Hearings are called when any of the following circumstances arise (rules 1 and 4):

(a) a player has been ordered off the playing enclosure.

The referee (and touch judge if involved) submits a report to the committee within 48 hours, giving the reasons and circumstances of the sending-off (rules 5 , 6). Players must be informed of hearings (rule 7) and referees must attend (rule 9).

71 R B Squire, Interview Notes, 10 July 1998.

72 Rules for Disciplinary Hearings (4 ed, New Zealand Rugby Football Union, 1998).

73 South African, New Zealand and Australian Rugby. 
(b) complaints are received.

Both Union and Judicial Committees can hear complaints about any acts not detected by the referee and touch judges (rules 23-30). Any person can lay a complaint including the chief executive of the NZRFU or his nominee, provincial unions, clubs, referees' associations or members of the public (rules 23-30, rules 96-109). For Judicial Committee matters, the NZRFU Disciplinary Commissioner can lay a complaint even if the act was detected and dealt with by match officials (rule 97(1)). Complaints in writing are sent to the relevant body within 48 hours (rules 25, 98).

Complaints are reviewed by the Complaints Review Officer (CRO) who determines whether it is "frivolous, vexatious or otherwise without merit" (rules $28(1), 101(1)$ ). If the complaint would not warrant an ordering-off and the player has not had a hearing in the previous six months, a written caution is issued. If the CRO determines the complaint should go to a hearing, all parties are notified and reports sought from relevant parties. (rules 27-30, rules 100-101).

CROs do not have to give reasons for their decisions and there are no rights of appeal from their decisions. (rule 136). A player, having received a written caution, can elect to have the complaint determined at a hearing (rule 28(3), rule 101(3)).

(c) a referee's report is submitted.

Where a referee believes that the decision he or she made was inappropriate, insufficient or incorrect in that no action was taken, a report can be submitted and is assessed by the CRO under the same grounds as other complaints (rules 31-36, 110-115).

(d) there was misconduct other than on playing enclosure.

Committees have the power to deal with misconduct by persons or clubs (affiliated to a union or the NZRFU) before, during or after the playing of a match "arising in a rugby setting" (rules 37(1), 116(1)).

(e) sinbin hearings - applies only to Union Disciplinary Committees.

The referee must send a written report on the circumstances of the sinbinning to the Union. If a player is sinbinned twice, he or she is informed that a further sinbinning during the same season will require a hearing and possibly a further penalty (rules 41-48). 


\section{Procedures at Hearings}

Each committee has the power to regulate procedure "as it thinks fit" (rules 11, 92). It must "endeavour to ensure" that the player attends the hearing but can make decisions in his or her absence (rule 8). It can adjourn or postpone hearings (rule 8) and provide interpreters (rule 10). All hearings are recorded and transcripts are available to any affected person (rules 22, 95). Proceedings are not invalidated for technical reasons as long as "there has been no miscarriage of justice" (rule 38).

The normal sequence of a hearing is that the Chairman explains the procedure, the referee's report is read and evidence from the player and any witnesses is heard. Videotape evidence (if accepted) is viewed. Witnesses cannot be questioned directly or cross-examined, except through the Chairman and at his discretion (rule 13). All parties can be represented by legal counsel or a duly authorised person (rules 16, 92, 104(3)).

Committees make their decisions in private (rule 17). Parties are informed of the decision orally followed by a written report explaining the reasons for the decision. Players are informed of their rights to appeal (rule 18).

Disciplinary proceedings may take place at the same time as any legal proceedings in a New Zealand court relating to the same matter, unless the Court orders otherwise (rule 141).

\section{Evidence}

Character evidence is admissible but is only relevant when determining the penalty (rule137(1)). Details of a player's earlier hearing can be given in evidence but are only relevant to the question of penalty (rule 137(2)). Both these types of evidence may be given following an ordering off, but at complaints' hearings can only be heard after the allegation is proved.

Each committee can receive evidence "as it thinks fit...notwithstanding the evidence may not be legally admissible" (rules 14, 105). Those entitled to be heard are the offending player, his or her union, the complainant, the referee and touch judges. Committees apply the "Best Evidence Rule" - first-hand accounts from persons actually present are given preference and while hearsay evidence is not inadmissible, less weight is given to it. Evidence presented as opinion is not permitted unless it is from experts, such as medical professionals.

\section{Burden of Proof}

Where the hearing arises from a complaint or misconduct, no penalty can be imposed unless the allegation is proved on the "balance of probabilities" (rule 131). 
For an ordering off or sinbinning hearing before a Judicial Committee, the committee cannot make a finding contrary to the referee's decision, but can review the referee's reasons for making that decision (rule 132(1)). Further, in hearings arising from a complaint, where the referee made a decision on the field of play, the Judicial Committee can review the referee's reasons for that decision (rule 132 (2)). Both rules state: "[T]he Judicial Committee shall not make a finding contrary to the referee's decision unless it is satisfied on the balance of probabilities on the evidence before it that the referee's decision is wrong" (rules 132(1) 132(2)).

The explanatory note says these rules comply with Law 6(5) of the Laws of the Game of Rugby Football which states: "During a match, the referee is the sole judge of fact and of law." This is interpreted as meaning that a referee's decision made during a match cannot be affected by rulings of a Judicial Committee. However, it is recognised that referees can make errors on the field. Rule 132 is designed to deal with any injustices which have arisen from the strict application of Law 6(5) by distinguishing the referee's reasons from the referee's decision, by finding that the referee's reasons for the decision were wrong. ${ }^{74}$

\section{Penalties}

Recommended penalties for offences range from one to three weeks suspension for non-dangerous "tripping" or "kneeing" to 24 to 36 months for "eye gouging" (rule 3A). Maximum penalties range from 10 weeks for "abuse" towards match officials to a life suspension for "head butting" or "a deliberate bodily act" (rule 3B). Monetary penalties up to $\$ 5000$ can be imposed (rule 49 ).

In applying penalties, each case is determined on its own merits but consideration is also given to:

(a) The need for consistency and uniformity.

(b) The level of penalties imposed by the Judicial Committee and the Appeal Council.

(c) The culpability of the conduct.

The severity of the victim's injury is a factor but is not determinative. The commencement of a penalty can be deferred if it would be meaningless during the offseason (rule134). Players may not play while their hearing is pending (rule 139). The NZRFU can suspend any club whose player fails to comply with the penalty. Provocation or acting in retaliation are not defences, but are factors taken into account when 
determining the penalty (rule 135). A new rule (rule 137(3)) recognises that persistent offending is a consideration when deciding the penalty. ${ }^{75}$

\section{Appeals from Union Disciplinary Committees}

Each union appoints an Appeal Committee (rule 51). Appellants can be the offending player (or their club), the victim player, a referees association or a complainant (rule 52). Appeals must be lodged within seven days (rule 51, 54).

Questions of fact arising on appeal are determined by the Appeal Committee by reference to the record of proceedings before the Disciplinary Committee. However, the Appeal Committee has the discretion to rehear the whole or any part of evidence, can hear further evidence "as it thinks fit" (rule 62) and can admit evidence notwithstanding it may not be legally admissible (rule 63). It can quash, vary or increase any penalty (rule 66).

A party, with the authority of their club or union, has a second level of appeal to the Judicial Committee of the NZRFU (rule 69) within seven days of the Appeal Committee's decision (rule 71). All appeals at this level are by way of re-hearing (rule 80). The decision of the Judicial Committee on appeal is final, except where special leave is granted to appeal to the Appeal Council (rule 86).

\section{Appeals from the Judicial Committee}

Appeals from the Judicial Committee are made to the NZFRU Appeal Council (rule 120) and must be lodged within seven days. The appeal is heard by way of a rehearing (rule 125). The decision of the Appeal Council is final.

\section{SANZAR (Super-12) and Tri-Nation Judicial Rules}

\section{Jurisdiction}

Super-12 and Tri-nation disciplinary matters are handled by three-member Judicial Committees, ${ }^{76}$ consisting of a Chairman, an eminent former player and either an eminent former rugby administrator or a lawyer with rugby judicial proceedings experience.

Judicial Committee hearings are held when: ${ }^{77}$

75 To comply with the spirit of Laws of the Game of Rugby Football, Law 26(2) Unfair Play, Repeated Infringements.

76 Super-12 Judicial Committees are set up in the most convenient area. The Chairman is appointed by the national union of the host country.

Tri-Nation Judicial Committees are set up at the match venue. The Chairman is appointed by the national union not involved in the match. The other two members are appointed by the host country. 
(a) A player is ordered off; or

(b) A citing is received from the Citing Commissioner; or

(c) A citing complaint is received from the management of either team.

\section{Citing Commissioner}

Each national union appoints a Citing Commissioner who can cite a player irrespective of whether the incident was detected or dealt with by match officials. The Citing Commissioner, whose decision is final, watches the game on television. To ensure offscreen or off-the-ball incidents are observed, a Liaison Officer attends and reports on the actual game.

\section{Procedure}

Each Judicial Committee can determine its own procedure, as long as it conforms with the agreed rules and complies with the "audi alteram partem" rule. ${ }^{78}$

Apart from the practice of using a Citing Commissioner, the procedures for hearings are essentially the same as in the Black Book.

\section{Appeals}

A player can appeal to the Appeals Tribunal, which adjudicates in the country which held the Judicial Committee proceedings. Appeals are by way of a rehearing and there is discretion to hear further evidence. The Tribunal can quash, vary, suspend or increase the penalty.

E Summary of Appeals - All Levels

\begin{tabular}{|l|l|l|}
\hline \multicolumn{1}{|c|}{ LOCAL / CLUB } & \multicolumn{1}{|c|}{ REP OR NPC } & TRI-NATIONS/SUPER-12 \\
\hline Union Disciplinary & Judicial Committee & Judicial Committee \\
\hline Appeal Committee & Appeal Council & Appeals Tribunal \\
\hline $\begin{array}{l}\text { Judicial Committee } \\
\text { Appeal Council (special } \\
\text { leave) }\end{array}$ & Court (Judicial Review) & $\begin{array}{l}\text { Court (Judicial Review) (on } \\
\text { Appeal) }\end{array}$ \\
\hline
\end{tabular}

77 SANZAR also have a sinbin and card system. Players are reported to host unions for appearance before the Judicial Committee of the national union if suspended or sinbinned on three or more occasions during SANZAR matches.

78 Broadly understood as meaning the rules of natural justice. 


\section{REVIEW OF THE NZRFU'S INTERNAL DISCIPLINARY PROCEDURES}

\section{A Hearings}

The NZRFU judicial model has been established to ensure that the process will meet the standards of fairness and proof required in a court. Hearings do not mirror a court process but do ensure that players hear the case against them and have an opportunity to be heard. There are many levels of appeal and proper jurisdiction is established at the outset of hearings. All parties have a right to legal representation and interpreters are provided where necessary.

\section{B The Role of Lawyers}

The judicial rules were designed and revised with considerable input from lawyers. The NZRFU believe that lawyers are better equipped to ensure the policy and procedures meet the standards of natural justice and fairness required. While there are lawyers on most Judicial Committees, there are also eminent ex-players and administrators, so the interests of players and the organisation are represented.

Another role for lawyers is representation of players at hearings. When the formal procedures were first introduced, lawyers were often employed by players. But some took an overly adversarial approach to the process ${ }^{79}$ and it became the trend for players to attend hearings either alone or with their team manager or coach. At local levels, this appears to be the most usual situation now.

However, at the Judicial Committee level, lawyers are more common. Professionals players could lose considerable amounts of money if suspended and legal representation is a safe option. ${ }^{80}$ Also, there are now some lawyers who have considerable experience with the process.

\section{Independence}

To be selected as a member of a NZFRU disciplinary committee, candidates must have some association with or experience of rugby. This raises the issue of whether committees can claim they act as truly independent bodies. Certainly, there are considerable advantages to the NZRFU as adjudicators will understand the pressures of the game and the limits of acceptable conduct. But it does not necessarily convince those outside rugby that foul play is being rigorously handled. A lack of independence could expose the

79 R B Squire, Interview Notes, 10 July 1998. D Bond, Interview Notes, 10 July 1998.

80 Loss of pay because of a disciplinary penalty is a matter of contract between the player and their local or national union. The disciplinary committees do not have the power to suspend players' income. 
NZRFU to criticisms that committees are merely 'slapping offenders' wrists' or the judicial process is a 'closed shop'. It could also fuel debate that criminal prosecution is the only independent option.

Further, it does not take rugby experience to know that eye-gouging or a punch in the head is violence. The employment of adjudicators from outside rugby circles would be one way for the sport to hear and provide for the non-rugby perspective on violence in rugby.

\section{Local Interpretation and Natural Justice}

The NZRFU requires that all provincial unions follow the Black Book procedures which emphasise that there must be fairness and natural justice in the entire disciplinary process: ${ }^{81}$

We believe the Revised Rules will achieve the objective of justice in rugby disciplinary proceedings, being dispensed in a fair, consistent, independent and expeditious matter. But no matter how perfect the system, ultimately it is the responsibility of Disciplinary

Committees to ensure that in all cases, justice not only is done, but is seen to be done.

The by-laws of the Wellington Rugby Football Union (WRFU) on disciplinary procedures reflect the main features of the Black Book and state: "The hearing will be conducted in accordance with disciplinary rules set by the NZRFU." 82

There is a notable difference, however, which may affect the requirements for natural justice and consistency throughout all levels. The WRFU's by-law 8.2.1 states that where a player has been ordered off, he or she is automatically suspended for two playing days (usually two weeks). On receipt of the referee's report, the player can either accept the report and the suspension or not accept them and demand a full hearing. If the player accepts them (which they do in many cases), ${ }^{83}$ he or she is not required to attend the disciplinary hearing but can send in written comments. A hearing is then held in the player's absence which may impose a further penalty. If the player does not accept the report and the automatic suspension, a full hearing is convened.

In the Black Book, there are no automatic penalties and this practice may be confined to the WRFU. ${ }^{84}$ It could be that the Black Book was written for the national body which

81 Rules for Disciplinary Hearings (4 ed, NZRFU, 1998) 22.

82 WRFU By-law 8.2.6(i).

83 In 1997, 36 out of 82 suspensions were for a two-week period. WRFU 1997 Annual Report and Statement of Accounts 41.

84 Both Auckland Rugby Football Union and Canterbury Rugby Football Union convene hearings every time a player is ordered-off. 
manages fewer games than a local district such as Wellington which in 1997 had 172 teams in the club competition. ${ }^{85}$ Both the Auckland and Christchurch unions say it takes considerable time and resources to organise hearings every week.

The major problem with the Wellington approach is the conflict with rules of natural justice. Firstly, the system makes an assumption of guilt and leaves the onus on the player to question that assumption. Secondly, the two-week suspension is arbitrary and conflicts with the NZRFU's policy that each case be treated on its individual merits and be consistent with recommended penalties in the Black Book. Thirdly, it does not give the player a full opportunity to be heard, unless he or she either challenges the penalty, or decides to go to a hearing after accepting it, which is unlikely. Also, the WRFU's distinction between a 'full' hearing and a hearing which may decide whether a further penalty is warranted is not provided for in the Black Book. While the Wellington process is a pragmatic way of dealing with the disciplinary procedures, it is potentially open to serious challenge and may be invalid.

\section{E Speed and Certainty}

An advantage of the internal procedures of the NZRFU, compared to police and court processes, is the certainty of apprehension and immediacy of punishment. Hearings are usually held in the week following the incident. Suspensions are immediate and a player cannot play rugby until after the hearing. Appeals are held within very short timeframes. Penalised players do not have an agonising wait to hear their fate, victim players can be sure that action will be taken immediately and the public perception is that hearings are handled expeditiously and decisively.

\section{F Victims}

The culture of rugby discourages victims of foul play from making complaints to the police and civil suits for injuries are a problematic area of law. Since the introduction of professionalism, however, a senior player may incur a loss of income if a prolonged injury period results from foul play. ${ }^{86}$ Lower grade players may lose wages from their employment after sick leave has been expended. With the recognised inadequacies in the ACC system, ${ }^{87}$ players may wish to pursue civil claims for gross negligence and seek exemplary damages.

85 WRFU 1997 Annual Report and Statement of Accounts 39.

86 The paid time-off allowed for injury will depend on the contract between the player and the NZRFU or local union.

87 See Stephen Todd (ed) The Law of Torts in New Zealand (2 ed, Brookers, Wellington, 1997) 92-94. 
It has been argued that the courts have not determined where the criminal boundaries lie in sports violence but professionalism has meant that "the civil law has stepped in where the criminal law has failed....[and]...we may see a hasty attempt to reconcile judicial claims that the purpose of exemplary damages...is to punish the wrongdoer rather than compensate the plaintiff." ${ }^{188}$ If civil claims were to occur in New Zealand, as they have in Australia, ${ }^{89}$ players (or their insurance companies) may also look to their employers, coaches or administrators for a remedy. ${ }^{90}$

The procedures do not allow for monetary compensation for the victim, but arguably they have other advantages. Firstly, hearings and appeals are resolved much more quickly than they would be in a criminal prosecution. Secondly, the burden of proof is lower than criminal standards and the victim can be cross-examined only at the Chairman's discretion. Thirdly, the procedures are considerably less formal than a courtroom and there is no adversarial process. A victim may not feel as alienated from the process as is common in criminal prosecutions.

A victim may be aggrieved that if the offence occurred outside the rugby field, the penalty would be greater than is received at a judicial hearing. However, as discussed earlier, the courts in New Zealand have not identified the point at which the consent of the victim cannot be a defence. Unless the conduct occurs after the final whistle, it is by no means certain that an offender would be convicted for violent acts on the rugby field.

\section{G Complexity}

Some complexity is unavoidable in the attempt to codify a process which is applicable at all levels of rugby. But a few rules seem overly complicated and some amendments have been made without explanation. For example, rule 132 and explanatory note distinguishes the referee's reasons from the referee's decision, the former able to be found wrong by a Judicial Committee, the latter being unchallengeable. If the Judicial Committee find the reasons for the decision to be wrong, they can make a finding contrary to the referee. It is unclear what this contrary finding could be except that the referee's wrong reasons led to a wrong decision and therefore, no further penalty will be imposed on the player. It is impossible to change the referee's decision after the fact, but it must be

88 Jayne Francis "Manly Diversions" [1997] NZLJ 158. See also: P W David "Sport and the Law - A New Field for Lawyers" [1992] NZ Recent Law Review 84.

89 See: Canterbury Bankstown Rugby League Football Club Ltd v Rogers; Bugden v Rogers [1993] Aust Tort Reps 81-246. Rogers was awarded $\$ 68,000$ after an illegal tackle meant he could not play for the rest of the season.

90 See also, Marianne Robinson "Sport and the Law in the 1990s" in Conference Papers Australia and New Zealand Sports Law Association Conference 1992. 
possible to say in hindsight that the decision was wrong. To distinguish the referee's reasons from the decision appears unnecessarily cumbersome and confusing.

Also, the 1996 edition of the Black Book gave the power to review referee's reasons to all disciplinary committees, not just the Judicial Committee. The preface to the 1998 edition does not say why this part of the rule has been changed. ${ }^{91}$

Another complexity is the use of the Latin terms: "mutatis mutandis"192 in the preface to 1998 Black Book and "audi alteram partem"93 in the SANZAR rules. While national and international committees have lawyer members, this is not so common at the union level. Given that the procedures are expected to be widely understood and applied by administrators and players and there is debate within the legal profession about the importance of 'plain English', 94 it is surprising that these terms are used.

\section{H Cost}

All local and national unions bear the cost of the internal disciplinary procedures. At the national level, this was not reported as a serious issue. But in the Wellington district, many hours of voluntary work are directed towards reviewing reports, contacting players, referees and committee members and conducting hearings.

One way to view the resource cost of the internal judicial process in rugby is that it is an inevitable consequence of rugby taking full responsibility for sportsfield violence. Firstly, the process relieves the state (and taxpayers) of the higher cost of criminal prosecution. Secondly, as long as the standards are maintained, the only way to reduce the cost is to lessen the incidence of violence. The financial incentive to do this and the consequences if it does not happen remains within rugby.

\section{The Expansion of the New Zealand Model}

An indication of the success of NZRFU disciplinary procedures is their acceptance by international bodies. The development of the SANZAR judicial rules were driven by the NZRFU and were based on the Black Book model. Also, despite some resistance from

91 It states that the change in rule 132 was a consequence of the amendment to rule 97, which extended the powers of Citing Commissioners. This does not explain the anomaly between the 1996 and 1998 editions.

92 "Shall apply to other circumstances with the necessary changes."

93 "Hear the other side" - broadly understood as meaning the rules of natural justice.

94 See: RC Wydick "Plain English for Lawyers" (1978) 66 Calif L Rev 727-765. 
Northern Hemisphere rugby nations, ${ }^{95}$ the Standard Tours Agreement provided by the IRFB gives two options to touring teams:

(a) A single commissioner who decides and rules on foul play, or

(b) A Judicial Committee procedure based on the SANZAR model. ${ }^{96}$

Inconsistency in international interpretation has been recognised as a problem. In 1997 the All Blacks were playing the Wallabies in Australia and Michael Brial, a Wallaby, attacked Frank Bunce off-the-ball, raining him with punches to his body. Television coverage caught the incident but it was not seen by the referee. While the NZRFU was horrified, the Australian Citing Commissioner decided that he would not cite the incident because it was just 'boys being boys'. ${ }^{97}$

\section{J The Trends}

It is difficult to assess whether incidents of foul play are decreasing because other factors such as improved vigilance, rule changes and better refereeing distorts figures from one year to the next. Actual numbers for hearings at the national level were not available, but in Wellington there was a significant decrease in players ordered-off between 1994 (191) and 1995 (65). However, since 1995 the numbers of players ordered-off and temporary suspensions ( $\sin$ bins) have increased about 10 percent per year. ${ }^{98}$

There do not appear to be any nationally collected statistics on the incidents of foul play and hearings. ${ }^{99}$ Also, there are no formal systems of quality control of the disciplinary procedures by the NZRFU, apart from ongoing revision of the Black Book.

It may be useful for administrators of rugby to measure and evaluate which aspects of the game are most at risk of foul play and develop programmes to deal with these. For example, it was said that 80 to 90 percent of hearings resulted from incidents occurring in the last four to five minutes in a game where the offending player was on the losing side. ${ }^{100}$ Initiatives could be developed to target this or any other problem, particularly if they are identified as a national trend.

95 There is a general perception in SANZAR countries that Northern Hemisphere Rugby Unions are behind the times in many areas of rugby administration. R B Squire, Interview Notes, 10 July 1998.

96 This option was adopted for the Scotland vs Australia Tour in 1998.

97 R B Squire, Interview Notes, 10 July 1998.

98 Wellington Rugby Football Union Annual Reports 1994-1998.

99 Local unions have records of suspensions and players ordered off in their areas.

100 D Bond, Interview Notes, 10 July 1998. 
Women's participation in rugby is increasing but violent incidents are uncommon in their games. ${ }^{101}$ Perhaps there are lessons which men's rugby could learn from the female approach to sportsfield pressures. Also, whether the judicial process is appropriate for women, particularly given that most disciplinary committee members are men, may become a factor.

Despite the lack of data, there is a general perception by players, coaches and administrators that violence on the field has markedly diminished. Also, there has been a notable lack of media reports criticising violent incidents in rugby, although attacks on referees by spectators or between spectators have featured, most of which have resulted in police action. ${ }^{102}$ Another factor could be that club rugby is experiencing declining membership and coupled with less media coverage at this level, incidents may go unnoticed.

An interesting feature of the Super-12 competition in 1998 was media appearances prior to Judicial Committee hearings by the offending player expressing his remorse and the victim player saying he harboured no ill-feeling towards the offender and it was all just 'part of the game'. This could be interpreted as the offender (or his lawyer) positioning himself favourably in an attempt to reduce the penalty at the hearing. Alternatively, it may be a kickback against the judicial process from players implicitly saying: 'what happens on the field should stay on the field.' At a notable incident earlier in 1998, involving Ian Jones and Jason O'Halloran, the Judicial Committee said: ${ }^{103}$

We add one further observation. Prior to the hearing Jones elected to publicly release details of his answer to the citing complaint and the matter received extensive coverage in both the print and electronic media. We do not know whether Jones was advised to take that step or did so of his own volition, nor do we know what prompted it although we have our own views. In the absence of evidence clarifying those matters we confine ourselves to the observation that similar steps taken by players appearing before the Judicial Committee in future are unlikely to have advantageous consequences for them, as was the case in this instance.

\section{K Judicial Review and le Roux}

On 23 July 1994, Johan le Roux bit the ear of All Black captain, Sean Fitzpatrick, in an international game. The incident was not seen by the referee or touch judges although

101 In Wellington in 1997, one woman rugby player was ordered off (compared to 83 men).

102 See: "Competitiveness at Core of Abuse" The Evening Post, Wellington, New Zealand, 19 July 1997, 14.

103 Ian Jones NZRFU Judicial Committee (16 March 1998). 
Fitzpatrick complained to the referee immediately. It was shown on television and a complaint was made to the NZRFU by the Disciplinary Commissioner. ${ }^{104}$ At the hearing, it was uncontested that the biting occurred and the Judicial Committee imposed a 19months suspension. ${ }^{105}$ Le Roux appealed the penalty saying it was excessive given other similar cases and the circumstances of this incident. The Appeals Committee dismissed the appeal. ${ }^{106}$ Le Roux applied to the High Court for judicial review. ${ }^{107}$

Le Roux argued that the Appeal Committee should not have considered the deterrence factor or that the incident was abhorrent to the rugby community. Eichelbaum CJ disagreed:

One of the matters any rugby union disciplinary body may properly have in mind in deciding on penalties is the image of the sport...Whether mentioned explicitly or not the question of deterrence is a matter that may appropriately be taken into account on every occasion... . 108 Denunciation is a proper and commonplace function of sentencing... . 109

Le Roux said that relevant considerations not considered were the circumstances surrounding his offence compared to those of Richard Loe in 1992 and Joseph Veitayaki in 1990. ${ }^{110}$ These included: Loe attacked the eye, whereas le Roux bit an ear and no serious injury resulted; neither Loe nor Veitayaki were provoked, whereas Fitzpatrick had illegally taken le Roux out of play; Loe and Veitayaki denied any intention whereas le Roux immediately apologised and pleaded guilty; Loe and Veitayaki's acts were deliberate compared to le Roux's split second loss of control. Further, mitigation factors considered in Loe's decision, such as family pressures, his contribution to rugby and loss of reputation and income, were not properly considered in the le Roux decision.

Eichelbaum CJ dismissed these arguments saying the lack of perfection in the appeal decision was because the committee were trying to release it as soon as was practicable.

104 Pursuant to the International Rugby Board Tours Agreement, Clause 17a.

105 From 25 July 1994 until 1 March 1996. Johan le Roux Judicial Committee (25 July 1994).

106 Johan le Roux Appeals Committee (1 August 1994).

107 Le Roux $v$ New Zealand Rugby Football Union Inc (14 March 1995) unreported, High Court, Wellington Registry, CP 346/94 [Le Roux v NZRFU].

108 Le Roux v NZRFU above n 107, 4-5.

109 Le Roux $v$ NZRFU above $\mathrm{n} 107,5$

110 Richard Loe was suspended for nine months (reduced to six months on appeal); Joseph Veitayaki was suspended for life (reduced to ten and a half months on appeal). 
Le Roux argued that the penalty was unreasonable being inconsistent, disproportionate to the offence and excessive being more than three times greater than Loe's suspension and twice the length of Veitayaki's. Eichelbaum CJ said that the NZRFU judicial process gave the committees discretion in penalties and the court would only interfere if the penalty was grossly disproportionate. He said that while "it seems high" in comparison with Loe's penalty and the NZRFU's own guidelines, it remained within "reasonable limits".111 Eichelbaum CJ dismissed the application.

Le Roux's counsel has said that the case shows how difficult it is for a lawyer to succeed, because the court is reluctant to "substitut[e] their decision for that of a domestic tribunal."112 He adds it is virtually impossible to prove that an internal judicial body has not considered relevant matters and "the honesty of a tribunal is not something that can rightfully have much weight in applications for judicial review."113 Given the huge disparity between le Roux's penalty with those imposed on Loe and Veitayaki the question has been rightly posed: "How disproportionate would a sentence have to be before a court in New Zealand would intervene?"114

\section{$V$ CONCLUSION}

Internal disciplinary procedures in sports organisations can be an effective way to deal with violence on the sportsfield. In developing its system, the NZRFU were faced with a dilemma. How could it ensure it did not remove the incentive for players to play hard but fair, but remove the danger from indulgence in foul play? The NZRFU's response was to provide the rugby world with a unique model which could be adopted by other codes, particularly those with high levels of contact and potentially serious risks of injury to players.

Lawyer involvement in the development and revision of the procedural rules has ensured that strong emphasis is placed on the principles of natural justice. However, the design of perfect procedural rules is not enough. The NZFRU must ensure they are applied consistently and fairly throughout all levels of the sport. Also, it must demonstrate that because of the effectiveness of the rules, violence in rugby is decreasing.

This paper has pointed to a few areas which need attention. Firstly, there is the problem of local interpretation where the WRFU have introduced an automatic penalty

111 Le Roux $v$ NZRFU above n 107, 15.

112 Garth Gallaway "Judicial Review - An Impossible Dream" Conference Papers - 5th annual Australia and New Zealand Sports Law Association Conference (July 1995) 20 [Judicial Review].

113 Gallaway "Judicial Review" above n 112, 22.

114 Gallaway "Judicial Review" above n 112, 20. 
system. While it is a pragmatic option, it exposes the decisions to challenge as being breaches of natural justice. Secondly, there is the issue whether the disciplinary committees can claim to be independent, when the main criterion for membership is the extent of a member's association with rugby. Increased participation by laypersons in the judicial process may be one option for the NZRFU. Thirdly, there is unnecessary complexity in some parts of the written procedures. Fourthly, there appears to be a lack of nationally collected data on both the number of hearings, the quality of decisions and the areas in rugby which present the greatest risk for violent incidents.

Finally, while judicial review of NZRFU disciplinary decisions has been unsuccessful for applicants, it does not lessen the important role of the mechanism. The legal issues in many areas of rugby are more important than ever before and the impact of professionalism has changed the relationship between players and the NZRFU. Also the public interest in rugby is immense. With these factors in mind, it may be necessary for the courts to take a more pro-active approach in reviewing the NZRFU's disciplinary decisions. 